Open Access

\title{
Smartness that matters: towards a comprehensive and human-centred characterisation of smart cities
}

\author{
Alexander Prado Lara', Eduardo Moreira Da Costa ${ }^{1}$, Thiago Zilinscki Furlani ${ }^{1}$ and Tan Yigitcanlar ${ }^{2^{*}}$ (D)
}

\author{
* Correspondence: tan.yigitcanlar@ \\ qut.edu.au \\ ${ }^{2}$ Civil Engineering and Built \\ Environment, Queensland University \\ of Technology (QUT), 2 George \\ Street, Brisbane QLD 4001, Australia \\ Full list of author information is \\ available at the end of the article
}

\begin{abstract}
The term 'smart cities' is a widely used, but at the same time a highly fuzzy concept. The fuzziness hinders our understanding on the benefits of its adoption, and explains the existence of many relevant activities with fragmented or distorted views of what a truly smart city is. The aim of this paper is to undertake a comprehensive review of how smart cities are perceived in the literature and in the light of the findings propose a clearer definition. Overview of the key terms, concepts and definitions associated to smart cities, reported in this paper, demonstrates that the definitions found in the academic literature have limited scope, and are overly focused on strategic drivers and specific actions, instead of making explicitly the connection between the concept of smart cities and the creation of environments that promote happiness and wellbeing of their residents - which should be the main function of a city. Following the thorough review on the smart cities literature, the paper proposes a comprehensive, human-centred, and context-free definition for smart cities. This definition brings an endogenous view on smart cities in which the central element is the direct participation of local actors and stakeholders in the process of thinking, defining, planning, and executing social, technological and urban transformations in cities.
\end{abstract}

Keywords: Smart cities, Smart communities, Smart urban technologies, Innovation, Human-centred cities, Urban planning and development

\section{Introduction}

Over the past decade smart urban technologies have begun to blanket our cities, forming the backbone of a large intelligent infrastructure. Along with this development, dissemination of the sustainability ideology has had a significant imprint on the planning and development of our cities (Yigitcanlar 2016). Consequently, the concept of smart cities, evolved from intelligent cities (see Komninos 2008), has become a popular topic particularly for scholars, urban planners, urban administrations, urban development and real-estate companies, and corporate technology firms. There are numerous perspectives on what a smart city is. These are ranging from purely ecological (Lim and Liu 2010) to technological (Townsend 2013), and from economic (Kourtit et al. 2012) to organisational (Hollands 2015) and societal (Deakin and $\mathrm{Al}$ Waer 2011; 2012) views. Moreover, as for Kitchin (2015), smart city symbolises a new kind of technology-led urban utopia. Utopia or not, in all these perspectives the vision

(C) 2016 The Author(s). Open Access This article is distributed under the terms of the Creative Commons Attribution 4.0 International License (http://creativecommons.org/licenses/by/4.0/), which permits unrestricted use, distribution, and reproduction in any medium, provided you give appropriate credit to the original author(s) and the source, provide a link to the Creative Commons license, and indicate if changes were made. 
of technology and innovation is a common ground to shape our cities into a form that we want to leave to our descendants. In this paper, the smart cities concept is viewed as a vision, manifesto or provocation-encompassing all techno-economic, technosocietal, techno-spatial, and techno-organisational domains-aiming to constitute the ideal 21st century city form. Presently, there is no fully-fledge smart cities exist. Stated by Glasmeier and Christopherson (2015, p. 4), "[t]he global smart city market will be valued at $\$ 1.6$ trillion in 2020 . Over 26 global cities are expected to be smart cities in 2025, with more than $50 \%$ of these smart cities from Europe and North America". At the moment with the building of these cities underway in a number of places around the world, smart city examples abound in both the popular media and in academic discussions. This provides us the ability to systematically re-evaluate the definition of smart cities.

\section{Various smart cities approaches}

Both academia and practitioners have introduced a myriad of terms and definitions related to building the cities of the future and the future of the cities by using the state-of-the-art information and communication technologies (ICTs): smart, intelligent, ubiquitous, digital, knowledge, sustainable, green, creative, innovative, and so on (Abdoullaev 2011; Nam and Pardo 2011; Wolfram 2012; Lara et al. 2013; Yigitcanlar 2015). Despite being possible to identify the particularities of the concepts and initiatives linked to either term, all of them are introduced as answers to the same set of issues related to urban agglomerations. Among those urban mobility, security, biosphere degradation, energy and food shortages, combating poverty, as well as creating new options for urban planning, innovation incentives, economic and social development stand out as the most popular ones (Carrillo 2006; Yigitcanlar 2011; Neirotti et al. 2014). This basically is the main reason why they can be seen as construction layers (Abdoullaev 2011) or application domains (Neirotti et al. 2014) of what some scholars (Nam and Pardo 2011; Wolfram 2012; Neirotti et al. 2014) generically refer to as smart cities. Although the concept of smart cities and many scholars share target problems, there is not a common and context-free smart cities view that clearly explains to city policymakers what a smart city is. Neirotti et al. (2014) highlights this very problem as one of the main obstacles to the diffusion process of smart cities initiatives. The fuzziness of the concept is a major obstacle in convincing urban policymakers and administrators to invest further in smart city initiatives to transform their cities (Hollands 2008; Abdoullaev 2011; Wolfram 2012).

\section{Does innovation make a city smart?}

Innovation is an integral part of the concept of smart cities. A large number of studies investigated the role of innovation in establishing a competitive edge in companies, communities and cities (Fernández-Jardón et al. 2014; Gadille and Siarheyeva 2014; Lepik and Krigul 2014; Romano et al. 2014; Yigitcanlar 2014; Mellor 2015; Park and Lee 2015; Yun 2015; Kim et al. 2016; Yun et al. 2016). Furthermore, the important role of open innovation for smart city formation is discussed in the literature. For example, according to Yun et al. (2015), strengthening open innovation, through companies setting it as a corporate strategy, will help in the development of knowledge-based urbanisation, and provide continued 
economic and innovative opportunities for smart cities. Innovation and technology solutions generated locally used for meeting the needs of the city and its communities will surely make a smart city independent and economically sustainable (Yigitcanlar et al. 2016). However, innovation alone is not the sole ingredient of success in establishing smart cities (Gaffney and Robertson 2016; Yigitcanlar 2016).

\section{Is smart better and if so for whom?}

The concept of smart cities brings large number of critical questions in mind. For instance, will a city that is guided solely by the concepts and definitions and also evaluates its actions by some set of indicators (see Giffinger et al. 2007 and Sarimin and Yigitcanlar 2012) seen in the smart cities literature automatically become a better place to live, work, study and have fun? Although improving mobility of people in the city, for instance, or any other of domains proposed by Giffinger et al. (2007) would meet the basic needs of residents, would it be enough to address all the subjective conditions (Ryan and Deci 2001; Diener 2009; Ballas 2013) that lead to the wellbeing of residents which is ultimately what really matters? Moreover, whatever the answers to these questions, would they be valid in any culture or locality? Völker et al. (2007), Mohnen et al. (2011) and Ballas (2013) in their studies highlight the difficulty in measuring or predicting people's satisfaction with the place they live, and the need to incorporate an anthropocentric view to the planning of actions related to the promotion of wellbeing and quality of life in the urban context. In this sense, Professor Richard Sennett's paper in The Guardian (2012) is symptomatic when it states that if some of the projects that are underway in the cities are synonym for intelligence, and then maybe it is preferable that cities maintain a degree of stupidity (also see World Press 2014).

\section{People at the centre of debate}

One can imagine that at least part of the resistance and criticism towards the term and the smart cities approach itself could be minimised if the concept did not leave any doubt that the construction or transformation of any urban agglomeration into a smarter city has to start from the premise of being integrated to the wishes, interests and needs-both current and potential-(Rizzo et al. 2013) of its residents and also of producing positive practical impact on their daily lives. From this premise, we single out from all the available definitions of smart cities what are their central elements, before proposing a wider definition, which can meet the goal of guiding academicians and practitioners-both in the conceptualisation of smart cities and in building the future cities that residents will be proud of.

\section{Approaches and definitions of smart cities}

\section{Smart cities foundations}

Literature review in general and the analysis of the particular works of Nam and Pardo (2011) and Neirotti et al. (2014) suggest the existence of four key foundations or macro application domains for the approaches of smart cities (including variations of terms), listed below and also illustrated in Fig. 1: 


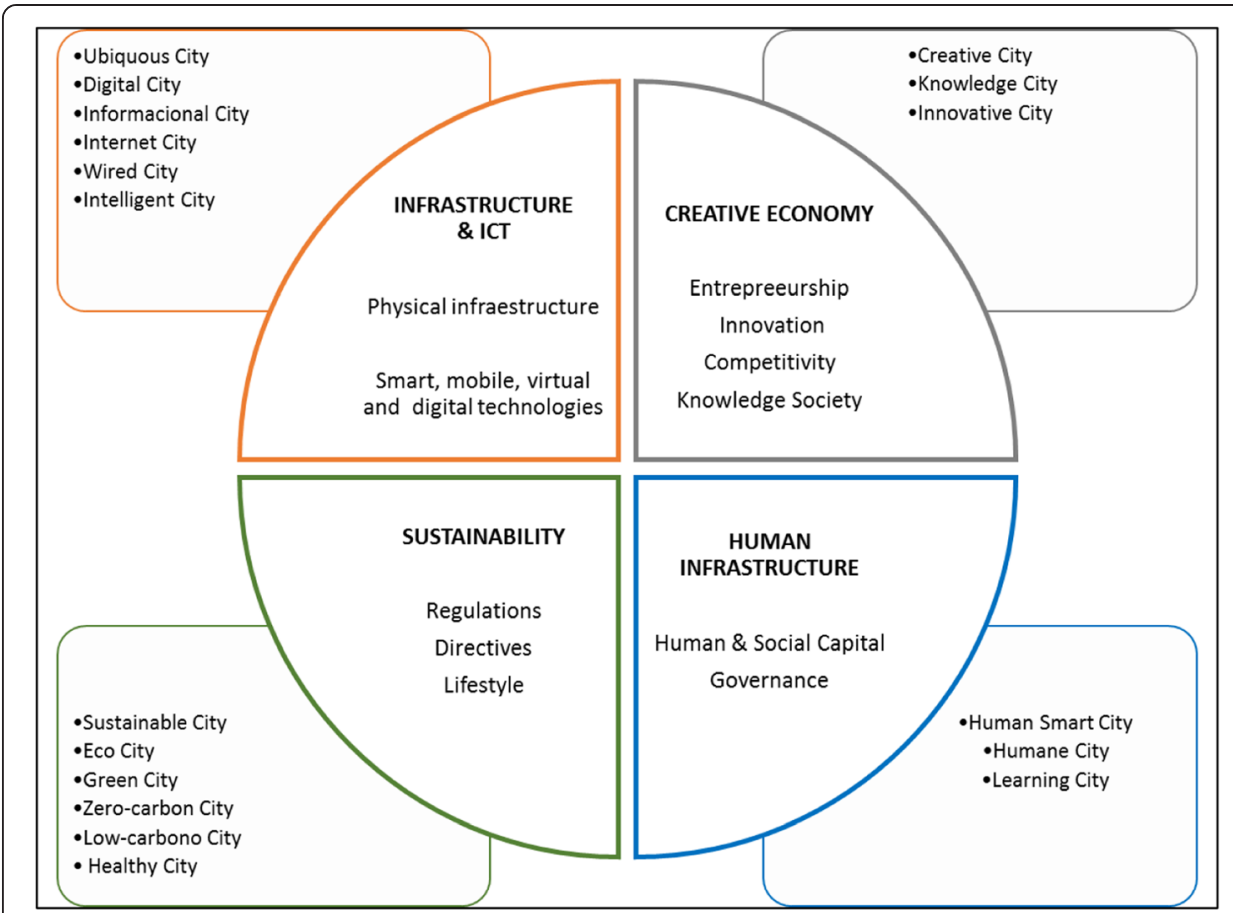

Fig. 1 Domains, terms and key issues in smart cities (adapted from Nam and Pardo 2011)

(i) Infrastructure and ICTs: Adoption of strategies for economic and social development founded on the provision of modern infrastructure, especially in the pervasive use of ICTs (Steventon and Wright 2006; Lee 2009; Piro et al. 2014);

(ii) Creative economy and knowledge-based society: Improving competitiveness and alignment to the so-called knowledge economy (Komninos 2006, 2009) with focus on creating favourable environments to entrepreneurship, creativity and innovation (Florida 2005; Lu et al. 2011; Yigitcanlar 2014; Yigitcanlar et al. 2015);

(iii) Sustainability: Promoting green economy and high social awareness in an environmentally sustainable lifestyle including a quality of life and place (Munier 2007; Yigitcanlar and Lee 2014), and;

(iv) Human infrastructure: Investment in social and human capital; engaging citizens in governance processes and the building of partnerships between public and private sectors to facilitate activities and projects (Streitz 2011; Rizzo et al. 2013).

\section{Adjusting the focus}

The choice of the term and the text that defines smart cities reflect the emphasis that each author gives to a certain domain, or to the set of strategies they suggest as the best way to build this kind of cities. Table 1 shows a compilation of key domains, terms and the definitions of city brands relate to smart cities. On the one hand, one could say that these terms represent fragmented proposals of the smart cities approach (e.g., Abdoullaev 2011). On the other hand, they ensure cohesion among academicians and practitioners, since they are based on a minimally shared vision between academic work and practical initiatives 
Table 1 Domains, terms and definitions of city brands relate to smart cities

\begin{tabular}{|c|c|c|}
\hline Domains & Terms & Definitions \\
\hline \multirow[t]{4}{*}{ Infrastructure \& ICTs } & $\begin{array}{l}\text { Ubiquitous } \\
\text { city }\end{array}$ & $\begin{array}{l}\text { An urban space where ubiquitous technologies are embedded } \\
\text { into the physical objects and structures in order to make urban } \\
\text { functions more efficient and consequently improve the quality } \\
\text { of people's life (Lee 2009, p. 11). }\end{array}$ \\
\hline & Digital city & $\begin{array}{l}\text { A digital city is a community digital space, which is used } \\
\text { to facilitate and augment the activities and functions } \\
\text { taking place within the physical space of the city } \\
\text { (Komninos 2006, p. 15). }\end{array}$ \\
\hline & $\begin{array}{l}\text { Smart } \\
\text { community }\end{array}$ & $\begin{array}{l}\text { A community in which government, business, and residents } \\
\text { understand the potential of information technology, and } \\
\text { make a conscious decision to use that technology to } \\
\text { transform life and work in their region in significant and } \\
\text { positive ways (Lindskog 2004, p. 13). }\end{array}$ \\
\hline & $\begin{array}{l}\text { Informational } \\
\text { city }\end{array}$ & $\begin{array}{l}\text { The informational city consists of creative clusters and } \\
\text { spaces for personal contacts to stimulate sharing of } \\
\text { implicit information (Stock 2011, p. 963). }\end{array}$ \\
\hline \multirow[t]{4}{*}{$\begin{array}{l}\text { Creative economy \& } \\
\text { knowledge-based } \\
\text { society }\end{array}$} & Intelligent city & $\begin{array}{l}\text { Intelligent cities and regions are territories with high capacity } \\
\text { for learning and innovation, which is built-in the creativity of } \\
\text { their population, their institutions of knowledge creation, and } \\
\text { their digital infrastructure for communication and knowledge } \\
\text { management (Komninos 2006, p. 13). }\end{array}$ \\
\hline & Creative city & $\begin{array}{l}\text { Broadly, creative cities is about how local urban spaces can be } \\
\text { re-imagined, rejuvenated, and re-purposed within a competitive } \\
\text { global framework (Tay 2004, p. 220). }\end{array}$ \\
\hline & $\begin{array}{l}\text { Knowledge } \\
\text { city }\end{array}$ & $\begin{array}{l}\text { A knowledge city is a place where new knowledge is constantly } \\
\text { being created. An entire social system is devoted to produce, } \\
\text { share and apply knowledge, which in turn, can be leveraged } \\
\text { and exploited by companies and organisations } \\
\text { (Ergazakis, Metaxiotis, and Psarras 2004, p. 79). }\end{array}$ \\
\hline & $\begin{array}{l}\text { Innovative } \\
\text { city }\end{array}$ & $\begin{array}{l}\text { Innovative city is an urban development pattern, in which } \\
\text { we solve the city problem with creative solutions to achieve } \\
\text { urban renaissance, and employ innovation as a driver of } \\
\text { sustainable urban development. (Lu et al. 2011, p. 2) }\end{array}$ \\
\hline \multirow[t]{3}{*}{ Sustainability } & $\begin{array}{l}\text { Sustainable } \\
\text { city }\end{array}$ & $\begin{array}{l}\text { A sustainable city is one in which the community has agreed } \\
\text { on a set of sustainability principles and has further agreed } \\
\text { to pursue their attainment. These principles should provide } \\
\text { the citizenry with a good quality of life, in a liveable city, } \\
\text { with affordable education, healthcare, housing, and } \\
\text { transportation (Munier 2007, p. 43). }\end{array}$ \\
\hline & Eco-city & $\begin{array}{l}\text { An eco-city is an ecologically healthy city. It is a healthy human } \\
\text { ecological process leading to sustainable development within } \\
\text { the carrying capacity of local ecosystems through changes in } \\
\text { the production mode, consumption behaviour and decision } \\
\text { instruments based on ecological economics and systems } \\
\text { engineering (Wang and Ye 2004, p. 341). }\end{array}$ \\
\hline & $\begin{array}{l}\text { Zero-carbon } \\
\text { city }\end{array}$ & $\begin{array}{l}\text { A 'zero-carbon city' is a city that entirely runs on } \\
\text { renewable energy and hence produces no carbon } \\
\text { footprint (Yigitcanlar and Lee 2014, p. 101). }\end{array}$ \\
\hline \multirow[t]{2}{*}{$\begin{array}{l}\text { Human } \\
\text { infrastructure }\end{array}$} & $\begin{array}{l}\text { Human } \\
\text { smart city }\end{array}$ & $\begin{array}{l}\text { Application of citizen-centric and participatory approaches to } \\
\text { the co-design, development, and production of smart cities } \\
\text { services that balance the technical 'smartness' of sensors, } \\
\text { meters, and infrastructures with softer features such as clarity } \\
\text { of vision, citizen empowerment, social interaction in physical } \\
\text { urban settings, and public-citizens partnership } \\
\text { (Rizzo et al. 2013, p. 677). }\end{array}$ \\
\hline & Humane city & $\begin{array}{l}\text { Places and environments where people enjoy everyday } \\
\text { life and work have multiple opportunities to exploit their } \\
\text { human potential and lead a creative life (Streitz 2011, p. 429). }\end{array}$ \\
\hline
\end{tabular}


Table 1 Domains, terms and definitions of city brands relate to smart cities (Continued)

\begin{tabular}{ll}
\hline Learning city & $\begin{array}{l}\text { A learning city, town or region recognises and understands } \\
\text { the key role of learning in the development of basic prosperity, } \\
\text { social stability and personal fulfilment, and mobilises all its human, } \\
\text { physical, and financial resources creatively and sensitively to develop } \\
\text { the full human potential of all its citizens (Longworth 1999, p. 4). }\end{array}$ \\
\hline
\end{tabular}

that adopt them, unlike the 'mishmash' of smart cities definitions (Fernandez-Maldonado and Romein 2010; Nam and Pardo 2011; Neirotti et al. 2014).

\section{Smart cities definitions}

The focus group on smart and sustainable cities connected to the International Telecommunication Union (ITU), a United Nations specialised agency for ICTs, has gathered 100 separate definitions of smart cities gathered from scientific undertaken in private companies, governments, research institutions, industry associations and NGOs activities or articles, newspapers and magazines (ITU 2014). Some of those definitions are listed in Table 2. The most striking feature of this set of definitions is the operational

Table 2 Common definitions of smart cities

\begin{tabular}{ll}
\hline Authors & Definitions \\
\hline $\begin{array}{l}\text { Bowerman et al. } \\
\text { (2000) }\end{array}$ & $\begin{array}{l}\text { A city that monitors and integrates conditions of all of its critical infrastructures including } \\
\text { roads, bridges, tunnels, rails, subways, airports, sea-ports, communications, water, power, } \\
\text { even major buildings, can better optimize its resources, plan its preventive maintenance } \\
\text { activities, and monitor security aspects while maximising services to its citizens. }\end{array}$
\end{tabular}

Giffinger et al. A city well performing in a forward-looking way in [economy, people, governance, (2007) mobility, environment, and living] built on the smart combination of endowments and activities of self-decisive, independent and aware citizens.

Rios (2008) A city that gives inspiration, shares culture, knowledge, and life, a city that motivates its inhabitants to create and flourish in their own lives. An admired city, a vessel to intelligence, but ultimately an incubator of empowered spaces.

Caragliu et al. (2009) A city to be smart when investments in human and social capital and traditional (transport) and modern (ICT) communication infrastructure fuel sustainable economic growth and a high quality of life, with a wise management of natural resources, through participatory governance.

Eger (2009) A particular idea of local community, one where city governments, enterprises and residents use ICTs to reinvent and reinforce the community's role in the new service economy, create jobs locally and improve the quality of community life.

González and Rossi (2011)

Nam and Pardo (2011)

Zhao (2011)

Lazaroiu (2012)

Schaffers et al. (2012)

Piro et al. (2014)

Yigitcanlar (2016)
A public administration or authorities that delivers (or aims to) a set of new generation services and infrastructure, based on information and communication technologies

A humane city that has multiple opportunities to exploit its human potential and lead a creative life.

Improving the quality of life in a city, including ecological, cultural, political, institutional, social, and economic components without leaving a burden on future generations.

The smart city represents the future challenge, a city model where the technology is in service to the person and to his economic and social life quality improvement.

Smart city is referred as the safe, secure environmentally green, and efficient urban centre of the future with advanced infrastructures such as sensors, electronics, and networks to stimulate sustainable economic growth and a high quality of life.

A smart city is intended as an urban environment which, supported by pervasive ICT systems, is able to offer advanced and innovative services to citizens in order to improve the overall quality of their life.

A smart city could be an ideal form to build the sustainable cities of the $21^{\text {st }}$ century, in the case that a balanced and sustainable view on economic, societal, environmental and institutional development is realised. 
focus, in particular the central role given to ICTs. Even when they minimise the importance of new technologies, most definitions are based on the prescription of strategic actions (Neirotti et al. 2014) and usually make much more explicit how the proposal advocated by the authors should be executed than why to do it and, more importantly, what does it aim to generate in people's lives. In other words, they are centred in the means such as the intensive use of new technologies, more open governance processes, or more sustainable strategies for economic and social development. Despite some attempts to produce a definition with a more holistic and integrated view, such as Caragliu et al. (2009), most smart cities definitions vary from a perspective centred on one of the four domains previously mentioned. There is not a shared vision (Neirotti et al. 2014), and there are no elements capable of giving significance-in the epistemological sense-to the term itself and the smart cities approach.

\section{In search of significance: smartness for what?}

The functional cities and the function of cities

In a utilitarian perspective, which sets the value (utility) of anything as its ability to produce pleasure or happiness and avoid pain and misfortune, an ideal society is one that: (i) Allows the fulfilment of the individual's happiness, as long as this does not compromise the wellbeing of the group, and; (ii) Seeks to maximise the level of satisfaction of the society-the greatest happiness for the greatest number (Rosen 2003). The Greek philosopher Aristotle (384-322 BCE) was already aware of the function of the city far beyond just providing ideal conditions for promoting development and creating prosperity. "The goal or purpose of the city certainly encompasses physical existence and survival, but is also more than that, namely, living 'finely' [...] The best city is happy and acts finely" (cited in Martin et al. 2003, p. 5). Aristotle understood the city primarily as a society, and happiness as a collective good that should pervade it. Therefore, if smart city is intended to be seen as a model of excellence, the term cannot leave any doubt that the promotion of the wellbeing and the happiness of its residents is a guiding principle and one of its key challenges (Ballas 2013).

\section{Smart cities are happier cities}

Despite the fact that wellbeing being a controversial concept also with an unresolved definition, it is known that both its meaning and the factors that condition it are linked to cultural aspects and are not free of value judgments and ethical positions (Ryan and Deci 2001). Several studies on the subject consider it inappropriate to deal with wellbeing as something that can be assessed simply from a universal set of conditions, such as income, marital status, individual freedom, and so on. Ryan and Deci (2001), Diener (2009) and Ballas (2013) show us that wellbeing and life satisfaction have objective and consistent conditions across cultures; but also a significant portion of subjective conditions, strongly influenced by local culture and circumstances. Moreover, in spite of having pan-cultural conditions, the importance that each society gives to them can differ substantially (Kitayama et al. 2000; Ryan and Deci 2001). This was already pointed out by a research conducted by Oishi et al. (1999), demonstrating that in poor nations income is a strong condition for life satisfaction, while satisfaction with family life is more important in richer nations. The same study suggests that individual freedom is less predictive of wellbeing in collectivistic societies than in individualistic ones. Daniel Kahneman, Nobel Prize in 
economics in 2002, argues that wellbeing and happiness are usually more related to subjective aspects such as the way we allot our time and the kind of social activities we engage into than to objective features (Kahneman et al. 2006). For these reasons, subjective aspects of wellbeing promotion should demand the same attention from city planners (Ballas 2013) as that they pay to its objective aspects. That is, in addition to providing quality of life-understood as levels of income, health, education, mobility, and so on-it would also be 'smart' to promote a lifestyle aligned with the values and other constituents of local culture (Ballas 2013; Neirotti et al. 2014).

\section{Sense of community and the endogenous producing of wellbeing}

The definition of 'sense of community' varies among different studies, but its constitution includes membership, mutual influence, fulfilment of needs, and shared emotional connection (Kim and Kaplan 2004) and reflects the feelings of attachment and belonging that an individual has towards the community (Pooley et al. 2005). According to Pooley et al. (2005), sense of community is equivalent to the social capital of a community, also called 'neighbourhood social capital' by Mohnen et al. (2011), which in turn defines it as "a resource one can access via membership in a group or community and consists of norms of reciprocity, civic participation, trust in others, and the benefits of membership" (Mohnen et al. 2011, p. 661). In the urban context, the most important benefit to be derived from joint activity with others is the realisation of goals related to physical and social wellbeing, and this importance is reinforced by evidences that neighbourhoods differ in their level of community and that such differences reflect in many relevant matters to people's lives (Völker et al. 2007; Han and Lee 2013). However, it is common sense and a phenomenon pointed out by social scientists that local neighbourhood communities are disappearing in present-day society as a side effect of growth and densification of cities (Wilson and Baldassare 1996; Völker et al. 2007).

\section{Supporting neighbourhood communities}

The key factor for the formation of a community is social interaction (Wilson and Baldassare 1996; Pancholi et al. 2015a, 2015b; Esmaeilpoorarabi et al. 2016), which is enhanced by the following three factors: (i) Opportunity for contact; (ii) Proximity to other people, and; (iii) Appropriate interaction spaces (Keane 1991). The physical-spatial reorganisation plays an important role in creating the sense of community, since it must provide formal and informal socialisation spaces (Talen 1999; Kim and Kaplan 2004). The same is said in relation to activities that strengthen social bonds, for example through actions that bring the neighbourhood together around the development of projects, shared purposes and goals (Lowe 2000; Völker et al. 2007). However, merely a proper planning and an incentive to social interaction (via processes of participatory governance, for example) seem unable to create such 'sense of community', especially its more 'affective' aspects (Talen 1999). Other variables, such as life pace, climate, size, density, diversity, economy, historical heritage and cultural identity must be considered, since they shape and make the experience of living in a given locality unique (Milgram 1974; Levine and Norenzayan 1999; Kim and Kaplan 2004; Völker et al. 2007). The construction of such psychological foundations of the sense of community depends on a number of factors that embed in citizens affective bonds with the place (Talen 1999). Such bonds are narrowed when residents are pleased with the 
community and familiar with its history and traditions, i.e., with the local narrative; when there is congruence or compatibility between the individuals personalities, the physical characteristics and the 'atmosphere' of the place; and when the place is able to awaken in its residents a sense of pride in being part of it (Talen 1999).

\section{Conclusions}

The concept of smart cities is currently a hot topic (see Yigitcanlar 2016). However, intense technology use alone in an urban environment does not equip this locality with the functionality of smart cities. Thus, it would be useful to underline what Caragliu et al. (2011) highlight as the key characteristics of smart cities, that are: (i) The utilisation of networked infrastructure to improve economic and political efficiency and enable social, cultural and urban development; (ii) An underlying emphasis on business-led urban development; (iii) A strong focus on the aim of achieving the social inclusion of various urban residents in public services; (iv) A stress on the crucial role of high-tech and creative industries in long run urban growth; (v) Profound attention to the role of social and relational capital in urban development, and; (vi) Social and environmental sustainability as a major strategic component for smart cities. Considering these key characteristics and the popularity of this type of city brand, we highlight below a new definition of the concept, its possible practical implications, linkages between smart cities and communities, and future directions.

\section{A new focus and definition}

In the light of the review of the literature, we propose a new smart city definition as follows. Smart city is "a community that systematically promotes the overall wellbeing for all of its members, and flexible enough to proactively and sustainably become an increasingly better place to live, work and play". Although this definition places people at the heart of smart city concept, it does not undermine the role of infrastructure, economy and sustainability - the four domains highlighted by Nam and Pardo (2011). Moreover, even being deliberately neutral in relation to the use of specific technologies or strategies, the definition implicitly incorporates the main approaches in literature, since that intelligence obviously manifests itself when the city promotes economic development with social justice and environmental sustainability; adopts and develops appropriate technologies for its local reality and uses governance processes that help build a community associated with the culture values and lifestyle its residents desire to retain or embrace (Neirotti et al. 2014). That, despite being simple, fulfils the role of being generic and comprehensive. In addition to being human-centred, as it brings promotion of wellbeing to the centre of the smartness concept, this definition imprints a dynamic character to the smart cities approach. Being smart is not just getting a high score on a set of metrics, even though this is a form of assessment. The definition implies the existence of neighbourhood communities (Talen 1999) with the goal of changing themselves for the best, on a continuous and sustainable way. In order to support this leading role; the community should be able to learn to build on their strengths and find their own way to become a better place for the current and future residents.

\section{Practical implications}

The main practical implication of this definition (or view of smart cities) is that any smart city project is set by and assessed from local cultural values point of view. For 
example, an appropriate smart cities proposal to São Paulo (Brazilian city known for its entrepreneurial, competitive and cosmopolitan inclination) may be completely unsuitable for the residents of Rio de Janeiro (another Brazilian city with strong values related to contemplation of the nature and balance between work and personal life). Thus, there must be reservations to replication proposals of successful projects imported from other cultures and geographies-even if they are in the same country (Ballas 2013; Neirotti et al. 2014). For the same reason, the work of planning the transformation of any territory into a smart city may require more than just good experts' directions. In order to establish a real understanding of the place, collaboration of people and institutions who actually understand the history and values of the community (including the future of it) is required. In other words, insiders are most likely to have better conditions to define what is relevant and useful (in the utilitarian sense), and to define priorities. These people and institutes also set what is secondary or undesirable for the community and city at any time. In addition to the continuous nature of the transformation process, it is assumed that potentially in the long run the most successful smart cities projects are the ones those made for with and eventually by the residents themselves. To paraphrase Ghandi, a smart city should create the conditions for people and institutions to be the change they wish to see in the city-derived from Mahatma Gandhi's statement of: "be the change you want to see in the world".

\section{Smart cities as the home of smart neighbourhood communities}

Considering a smart city as a set of one or more smart neighbourhood communities makes it human-centred and creates one of the pillars of cities smartness: participatory governance based on the engagement of civil society in the processes of urban transformation (Rizzo et al. 2013). From the individuals' point of view, the desirable emotional connection between the place and its residents suggests that planning a smart city needs to strongly engage its residents in the process of building the vision for the future. For some scholars, this involvement goes way beyond participating or providing feedback; it also includes helping in its building itself, through co-design and public-private-academia-community partnerships-so called quadruple helix model partnership (Rizzo et al. 2013). In this approach, individuals are seen as the producers of their own wellbeing by having a say and determining the features of their smart community/city (Völker et al. 2007).

\section{Future directions}

From the proposed definition of smart cities in this paper (a smart city is a community that systematically promotes the overall wellbeing for all of its members, and flexible enough to proactively and sustainably become an increasingly better place to live, work and play), two different research agendas emerge. These are: (i) How to start and drive the transformation process of places for them to become smart cities, and; (ii) How to assess the process of smart city transformation. The first agenda includes framework proposals for planning, initiating and managing transformation processes of a given geographical locality; it includes strategies, approaches, methods and techniques that help the actors involved in this challenge. The construction of frameworks may require identification, compilation or building of success cases (aligned with the humancentred perspective suggested in this paper). The second research agenda includes 
conducting studies that propose mechanisms to evaluate a locality, not only according to the metrics associated with the various domains of a smart city (Neirotti et al. 2014), but also their ability to autonomously conduct the transformation processes it will need to go through to become an even better place to live, work and play. This includes measuring its ability to identify, learn and do whatever needs to be done to ensure a better and sustainable future for its residents. In conclusion, success of smart cities concept depends on accurately determining the 'smartness that matters', and whatever smartness needs to be created it has to be done through a human-centred participatory processes to form successful smart cities and communities.

\section{Competing interests}

The authors wish to acknowledge the financial and in-kind contributions of Federal University of Santa Catarina, Queensland University of Technology, and the DGIST R\&D Program of the Ministry of Science, ICT \& Future Planning of Korea (14-IT) in supporting the research upon which this paper is based. The authors also thank anonymous referees who provided constructive comments on an earlier version that helped us improve the paper.

\section{Authors' contributions}

This paper represents a result of collegial teamwork. ALP, EMDC, and TZF designed the research and prepared the first draft of the manuscript. Tan Yigitcanlar finalized the manuscript, by incorporating his views and editing it thoroughly, and submitted to the journal. After the peer-review process, Tan Yigitcanlar revised the manuscript in the light of referee comments. All authors read and approved the final manuscript.

\section{Author details}

${ }^{1}$ Knowledge Engineering and Management, Federal University of Santa Catarina, R. Eng. Agronômico Andrei Cristian Ferreira, S/N - Trindade, Florianópolis 88040-900, Brazil. ${ }^{2}$ Civil Engineering and Built Environment, Queensland University of Technology (QUT), 2 George Street, Brisbane QLD 4001, Australia.

Received: 6 April 2016 Accepted: 27 May 2016

Published online: 23 June 2016

\section{References}

Abdoullaev, A. (2011). A smart world: a development model for intelligent cities. In The 11th IEEE International Conference on Computer and Information Technology (pp. 1-28).

Ballas, D. (2013). What makes a 'happy city'? Cities, 32(1), 39-50.

Bowerman, B., Braverman, J., Taylor, J., Todosow, H., \& Wimmersperg, U. (2000). The vision of a smart city. In 2nd International Life Extension Technology Workshop: Paris.

Caragliu, A., Bo, C. D., \& Nijkamp, P. (2011). Smart cities in Europe. Journal of Urban Technology, 18(2), 65-82.

Caragliu, A., Bo, C. D., \& Nijkamp, P. (2009). Smart cities in Europe. In 3rd Central European Conference in Regional Science (pp. 45-60).

Carrillo, F. J. (2006). Knowledge cities: approaches, experiences and perspectives. New York: Routledge.

Deakin, M., \& Al Waer, H. (2011). From intelligent to smart cities. Intelligent Buildings International, 3(3), 140-152.

Deakin, M., \& Al Waer, H. (2012). From intelligent to smart cities. New York: Routledge.

Diener, E. (2009). Culture and well-being. Berlin: Springer.

Eger, J. M. (2009). Smart growth, smart cities, and the crisis at the pump a worldwide phenomenon. The Journal of E-Government Policy and Regulation, 32(1), 47-53.

Ergazakis, K., Metaxiotis, K., \& Psarras, J. (2004). Towards knowledge cities: conceptual analysis and success stories. Journal of Knowledge Management, 8(5), 5-15.

Esmaeilpoorarabi, N., Yigitcanlar, T., \& Guaralda, M. (2016). Place quality and urban competitiveness symbiosis? A position paper. International Journal of Knowledge-Based Development, 7(1), 4-21.

Fernández-Jardón, C., Costa, R. V., \& Dorrego, P. F. (2014). The impact of structural capital on product innovation performance: an empirical analysis. International Journal of Knowledge-Based Development, 5(1), 63-79.

Fernandez-Maldonado, A. M., \& Romein, A. (2010). The role of organisational capacity and knowledge-based development: the reinvention of Eindhoven. International Journal of Knowledge-Based Development, 1(1-2), 79-96.

Florida, R. (2005). Cities and the creative class. New York: Routledge.

Gadille, M., \& Siarheyeva, A. (2014). Limits to the construction of a community-based open innovation network and implications for specialisation of a small urban area. International Journal of Knowledge-Based Development, 5(2), 152-172.

Gaffney, C., \& Robertson, C. (2016). Smarter than smart: Rio de Janeiro's flawed emergence as a smart city. Journal of Urban Technology. doi:10.1080/10630732.2015.1102423.

Giffinger, R., Fertner, C., Kramar, H., Kalasek, R., Pichler-Milanovic, N., \& Meijers, E. (2007). Smart cities: ranking of European medium-sized cities. Vienna: Vienna University of Technology.

Glasmeier, A., \& Christopherson, S. (2015). Thinking about smart cities. Cambridge Journal of Regions, Economy and Society, 8(1), 3-12.

González, J. A., \& Rossi, A. (2011). New trends for smart cities. Competitiveness and Innovation Framework Programme. Accessed on 7 May 2014 from http://opencities.net/sites/opencities.net/files/content-files/repository/D2.2. 21\%20New\%20trends\%20for\%20Smart\%20Cities.pdf.

Han, J. H., \& Lee, S. H. (2013). Planning ubiquitous cities for social inclusion. International Journal of Knowledge-Based Development, 4(2), 157-172. 
Hollands, R. G. (2008). Will the real smart city please stand up? City, 12(3), 303-320.

Hollands, R. G. (2015). Critical interventions into the corporate smart city. Cambridge Journal of Regions, Economy and Society, 8(1), 61-77.

ITU. (2014). Smart sustainable cities: an analysis of definitions by ITU-T Focus Group on Smart Sustainable Cities. Accessed on 7 May 2014 from http://www.itu.int/en/ITU-T/focusgroups/ssc/Pages/default.aspx.

Kahneman, D., Krueger, A. B., Schkade, D., Schwarz, N., \& Stone, A. A. (2006). Would you be happier if you were richer? A focusing illusion. Science, 312(5782), 1908-1910.

Keane, C. (1991). Socio-environmental determinants of community formation. Environment and Behavior, 23(1), 27-46.

Kim, J., \& Kaplan, R. (2004). Physical and psychological factors in sense of community new urbanist Kentlands and nearby Orchard Village. Environment and Behavior, 36(3), 313-340.

Kim, S. J., Kim, E. M., Suh, Y., \& Zheng, Z. (2016). The effect of service innovation on R\&D activities and government support systems: the moderating role of government support systems in Korea. Journal of Open Innovation: Technology, Market, and Complexity, 2(1), 1-19.

Kitayama, S., Markus, H. R., \& Kurokawa, M. (2000). Culture, emotion, and well-being: good feelings in Japan and the United States. Cognition and Emotion, 14(1), 93-124.

Kitchin, R. (2015). Making sense of smart cities: addressing present shortcoming. Cambridge Journal of Regions Economy and Society, 8(1), 131-136

Komninos, N. (2006). The architecture of intelligent cities integrating human, collective, and artificial intelligence to enhance knowledge and innovation. In 2nd International Conference on Intelligent Environments, Institution of Engineering and Technology (pp. 13-20).

Komninos, N. (2008). Intelligent cities and globalisation of innovation networks. New York: Routledge.

Komninos, N. (2009). Intelligent cities: towards interactive and global innovation environments. International Journal of Innovation and Regional Development, 1(4), 337-355

Kourtit, K., Nijkamp, P., \& Arribas, D. (2012). Smart cities in perspective: a comparative European study by means of self-organizing maps. Innovation: The European Journal of Social Science Research, 25(2), 229-246.

Lara, A. P., Marques, J. S., Santos, N., \& Costa, E. M. (2013). Projeto Florip@21: a construção de uma região inteligente na cidade de Florianópolis, Brasil. In Proceedings of XV Latin Iberian-American Congress on Management of Technology, Porto (pp. 1673-1691)

Lazaroiu, G. C. (2012). Definition methodology for the smart cities model. Energy, 20(1), 326-335.

Lee, S. H. (2009). Introduction to Ubiquitous city (pp. 10-28). Daejon: Hanbat National University Press.

Lepik, K. L., \& Krigul, M. (2014). Challenges in knowledge sharing for innovation in cross-border context. International Journal of Knowledge-Based Development, 5(4), 332-343.

Levine, R. V., \& Norenzayan, A. (1999). The pace of life in 31 countries. Journal of Cross-Cultural Psychology, 30(2), $178-205$.

Lim, C. J., \& Liu, E. (2010). Smartcities and eco-warriors. New York: Routledge.

Lindskog, H. (2004). Smart communities initiatives. In Proceedings of the 3rd ISOneWorld Conference (pp. 14-16).

Longworth, N. (1999). Creating lifelong learning cities, towns, and regions. A European Policy Paper. The TELS Project (Towards a European Learning Society).

Lowe, S. S. (2000). Creating community art for community development. Journal of Contemporary Ethnography, 29(3), 357-386.

Lu, Y., Zhu, Y., Li, J., \& Wu, K. (2011). The tale of two cities: the paths of innovative city in China. In International Conference of E-Business and E-Government (pp. 1-5).

Martin, T. R., Smith, N., \& Stuart, J. F. (2003). Democracy in the Politics of Aristotle. Classical Athenian Democracy, 26(7), 1-13.

Mellor, R. B. (2015). Modelling the value of external networks for knowledge realisation, innovation, organisational development and efficiency in SMEs. International Journal of Knowledge-Based Development, 6(1), 3-14.

Milgram, S. (1974). The experience of living in cities. Crowding and Behavior, 167(41), 1461-1468.

Mohnen, S. M., Groenewegen, P. P., Völker, B., \& Flap, H. (2011). Neighborhood social capital and individual health. Social Science \& Medicine, 72(5), 660-667.

Munier, N. (2007). Handbook on urban sustainability. Berlin: Springer.

Nam, T., \& Pardo, T. A. (2011). Conceptualizing smart city with dimensions of technology, people, and institutions In 12th Annual International Digital Government Research Conference: Digital Government Innovation in Challenging Times (pp. 282-291).

Neirotti, P., Marco, A., Cagliano, A. C., Mangano, G., \& Scorrano, F. (2014). Current trends in smart city initiatives: some stylised facts. Cities, 38(1), 25-36.

Oishi, S., Diener, E. F., Lucas, R. E., \& Suh, E. M. (1999). Cross-cultural variations in predictors of life satisfaction: perspectives from needs and values. Personality and Social Psychology Bulletin, 25(8), 980-990.

Pancholi, S., Yigitcanlar, T., \& Guaralda, M. (2015a). Public space design of knowledge and innovation spaces: learnings from Kelvin Grove Urban Village, Brisbane. Journal of Open Innovation: Technology, Market, and Complexity, 1(1), 1-17.

Pancholi, S., Yigitcanlar, T., \& Guaralda, M. (2015b). Place making facilitators of knowledge and innovation spaces: insights from European best practices. International Journal of Knowledge-Based Development, 6(3), 215-240.

Park, E., \& Lee, J. W. (2015). A study on policy literacy and public attitudes toward government innovation-focusing on Government 3.0 in South Korea. Journal of Open Innovation: Technology, Market, and Complexity, 1(1), 1-13.

Piro, G., Cianci, I., Grieco, L. A., Boggia, G., \& Camarda, P. (2014). Information centric services in smart cities. Journal of Systems and Software, 88(1), 169-188.

Pooley, J. A., Cohen, L., \& Pike, L. T. (2005). Can sense of community inform social capital? The Social Science Journal, $42(1), 71-79$.

Rios, P. (2008). Creating "the smart city". Accessed on 1 Mar 2016 from https://archive.udmercy.edu/handle/10429/393.

Rizzo, F., Concilio, G., Marsh, J., \& Molinari, F. (2013). The living lab approach to co-design solutions for human smart cities: lessons learnt from Periphèria Project. In Proceedings of Co-create Conference, Aalto University, Espoo, Finland (pp. 16-19). 
Romano, A., Passiante, G., Del Vecchio, P., \& Secundo, G. (2014). The innovation ecosystem as booster for the innovative entrepreneurship in the smart specialisation strategy. International Journal of Knowledge-Based Development, 5(3), $271-288$.

Rosen, F. (2003). Classical utilitarianism from Hume to Mill. London: Routledge.

Ryan, R. M., \& Deci, E. L. (2001). On happiness and human potentials: a review of research on hedonic and eudaimonic well-being. Annual Review of Psychology, 52(1), 141-166.

Sarimin, M., \& Yigitcanlar, T. (2012). Towards a comprehensive and integrated knowledge-based urban development model: status quo and directions. International Journal of Knowledge-Based Development, 3(2), 175-192.

Schaffers, H., Komninos, N., Tsarchopoulos, P., Pallot, M., Trousse, B., Posio, E., Carter, D. (2012). Landscape and roadmap of future internet and smart cities. Accessed on $17 \mathrm{Feb} 2016$ from https://hal.inria.fr/hal-00769715/document.

Steventon, A., \& Wright, S. (2006). Intelligent spaces: the application of pervasive ICT. Berlin: Springer.

Stock, W. G. (2011). Informational cities: analysis and construction of cities in the knowledge society. Journal of the American Society for Information Science and Technology, 62(5), 963-986.

Streitz, N. A. (2011). Smart cities, ambient intelligence and universal access. Berlin: Springer.

Talen, E. (1999). Sense of community and neighbourhood form: an assessment of the social doctrine of new urbanism. Urban Studies, 36(8), 1361-1379.

Tay, J. (2004). Creative industries. Malden: Blackwell.

The Guardian. (2012). No one likes a city that's too smart. Accessed on 1 Mar 2016 from http://www.theguardian.com/ commentisfree/2012/dec/04/smart-city-rio-songdo-masdar.

Townsend, A. M. (2013). Smart cities: big data, civic hackers, and the quest for a new utopia. New York: WW Norton \& Company.

Völker, B., Flap, H., \& Lindenberg, S. (2007). When are neighbourhoods communities? Community in Dutch neighbourhoods. European Sociological Review, 23(1), 99-114.

Wang, R., \& Ye, Y. (2004). Eco-city development in the People's Republic of China. Ambio, 33(6), 341-342.

Wilson, G., \& Baldassare, M. (1996). Overall sense of community in a suburban region the effects of localism, privacy, and urbanization. Environment and Behavior, 28(1), 27-43.

Wolfram, M. (2012). Deconstructing smart cities: an intertextual reading of concepts and practices for integrated urban and ICT development.

World Press. (2014). Smart cities? Not for me! Accessed on 1 Mar 2016 from https://professormikecampbell.wordpress. com/2014/02/28/smart-cities-not-for-me.

Yigitcanlar, T., \& Lee, S. H. (2014). Korean ubiquitous-eco-city: a smart-sustainable urban form or a branding hoax? Technological Forecasting and Social Change, 89(1), 100-114.

Yigitcanlar, T. (2011). Position paper: redefining knowledge based urban development. International Journal of Knowledge-Based Development, 2(4), 340-356.

Yigitcanlar, T. (2014). Innovating urban policymaking and planning mechanisms to deliver knowledge-based agendas: a methodological approach. International Journal of Knowledge-Based Development, 5(3), 253-270.

Yigitcanlar, T. (2015). Smart cities: an effective urban development and management model? Australian Planner, 52(1), $27-34$.

Yigitcanlar, T. (2016). Technology and the city: systems, applications and implications. New York: Routledge.

Yigitcanlar, T., Guaralda, M., Taboada, M., \& Pancholi, S. (2016). Place making for knowledge generation and innovation: planning and branding Brisbane's knowledge community precincts. Journal of Urban Technology. doi:10.1080/ 10630732.2015.1090198.

Yigitcanlar, T., Inkinen, T., \& Makkonen, T. (2015). Does size matter? Knowledge-based development of second-order cityregions in Finland. disP-The Planning Review, 51(3), 62-77.

Yun, J. J. (2015). How do we conquer the growth limits of capitalism? Schumpeterian Dynamics of Open Innovation. Journal of Open Innovation: Technology, Market, and Complexity, 1(1), 1-20.

Yun, J. J., Jeong, E., \& Yang, J. (2015). Open innovation of knowledge cities. Journal of Open Innovation: Technology, Market, and Complexity, 1(1), 1-20.

Yun, J. J., Won, D. K., \& Park, K. (2016). Dynamics from open innovation to evolutionary change. Journal of Open Innovation: Technology, Market, and Complexity, 2(1), 1-18.

Zhao, J. (2011). Towards sustainable cities in China: analysis and assessment of some Chinese cities in 2008. Berlin: Springer.

\section{Submit your manuscript to a SpringerOpen ${ }^{\circ}$ journal and benefit from:}

- Convenient online submission

Rigorous peer review

- Immediate publication on acceptance

- Open access: articles freely available online

- High visibility within the field

Retaining the copyright to your article

Submit your next manuscript at $\gg$ springeropen.com 